\title{
"PAYING UP" FOR RESEARCH: A REGULATORY AND LEGISLATIVE ANALYSIS
}

\author{
JAMES F. JORDEN*
}

On January 23, 1975, the Securities and Exchange Commission announced the adoption of rule $19 \mathrm{~b}-3$, putting an end to the era of minimum commission rates on the nation's stock exchanges. ${ }^{1}$ On May 23, Congress enacted the Securities Acts Amendments of 1975, ${ }^{2}$ provid-

* B.A., 1963, Dickinson College; LL.B., 1966, George Washington University Law School. Member of the Bar, Virginia and the District of Colunibia. Chairman, Subcommittee on Regulated Investment Companies, Tax Section of the American Bar Association, 1975-. Chairman, Division of Corporation, Finance and Securities Law, District of Colunibia Bar, 1974-.

THE FOLLOWING CITATIONS WILL BE USED IN THIS ARTICLE:

SECURITIES AND EXCHANGE COMMISSION, INSTITUTIONAL INVESTOR STUDY REPORT, H.R. Doc. No. 92-64, 92d Cong., 1st Sess. (1971) [hereinafter cited as InSTrrutionaL INVESTOR STUDY];

Securities and Exchange Commission, Report of Spectal Study of Securities MARKETs, H.R. Doc. No. 95, 88th Cong., 1st Sess. (1963) [hereinafter cited as Special STUDY];

Securities and Exchange Commission, Statement on the Future Structure of tHe SECURITIES MARKETS, 37 Fed. Reg. 5286 (1972) [hereinafter cited as Future Structure Statement].

1. SEC Securities Exchange Act Release No. 11,203, [1974-1975 Transfer Binder] CCH Fed. Sec. L. Rep. If 80,067 (Jan. 23, 1975). Throughout this Article, the Securities and Exchange Commission will be called either the Commission or the SEC.

2. Pub. L. No. 94-29, 89 Stat. 97 (June 4, 1975). Section $6(\mathrm{e})(1)$ of the bill as enacted provides:

On and after the date of enactment of the Seeurities Acts Amendnients of 1975, no national securities exchange may impose any schedule or fix rates of commissions, allowances, discounts, or other fees to be charged by its niembers: Provided, however, That until May 1, 1976, the preceding provisions of this paragraph shall not prohibit any such exchange fronl imposing or fixing any schedule of commissions, allowances, discounts, or other fees to be charged by its members for acting as broker on the floor of the exchange or as oddlot dealer: And provided further, That the Commission, in accordance with the provisions of section 19(b) of this title as nodified by the provisions of paragraph (4) of this section, nlay-

(A) permit a national securities exchange, by rule, to impose a reasonable schedule or fix reasonable rates of commissions, allowances, discounts, or other fees to be charged by its menibers for effecting transactions on such exchange prior to November 1, 1976, if the Commission finds that such schedule or fixed rates of commissions, allowances, discounts, or other fees are in the public interest; and

(B) permit a national securities exchange, by rule, to impose a schedule or fix rates of commissions, allowances, discounts, or other fees to be charged by its members for effecting transactions on such exchange after November 1, 1976, if the Commission finds that such schedule or fixed rates of commissions, allowances, discounts, or other fees (i) are reasonable in relation to the costs of providing the service for which such fees are charged (and the Commission publishes the standards employed in adjudging reasonableness) and 
ing a legislative mandate which had already been effected by the Commission's action. As a result, securities trades of all sizes are now subject to negotiation for the lowest price (consistent with best execution) by portfoho managers and investment advisers. In addition to the dilemma created by this action for brokerage houses, which had lobbied strongly against it out of concern for economic survival, ${ }^{3}$ this action by Congress and the Commission created unique problems for investment advisers and portfolio managers who had been obtaining research and other services from some brokers and paying for it as a part of the cost of executing brokerage transactions on behalf of accounts being managed by them. ${ }^{4}$ This Article will explore the background of these problems, the legislative amendment ${ }^{5}$ enacted by Congress to amehorate them, and the issues which remain notwithstanding the special amendment.

(ii) do not impose any burden on competition not necessary or appropriate in furtherance of the purposes of this title, taking into consideration the competitive effects of permitting such schedule or fixed rates weighed against the competitive effects of other lawful actions which the Commission is authorized to take under this title. Id. $\S 6(\mathrm{e})(1), 89$ Stat. 107-08.

3. The enormous effort of the New York Stock Exchange (NYSE) members in December of 1974 kept such legislation from passage in that year. See BNA SEC. REG. \& L. Rep. No. 282, at AA-1 (Dec. 18, 1974).

4. Throughout this Article, this problem is referred to as "paying up" or paying "soft dollars" for research. Where a commission to one broker is greater than that which would have to be paid another broker because of research services provided, the problem is characterized as "paying up." Any time that research is supplied for a portion of the commission paid for executing a securities transaction, such payment is referred to as paying "soft dollars" for research. Conversely, "hard dollar" research is defined as research purchased by the adviser (or the advisory account) directly for a specified sum and not as a part of any brokerage transaction. The problem is critical only where the investment adviser has the authority to designate the broker-dealer through whom a trade will be executed. Many accounts permit the customer to designate which brokerdealer should be used for executions. In the case of individual accounts, according to the Institutional Investor Study, mole than thirty percent of such accounts do not permit investment advisers (non-bank) to direct brokerage, and in thirty-six percent of such accounts, customer-designated brokers accounted for eighty-five percent of the executions. In the case of bank-managed personal accounts, these two figures were five percent and twelve percent. 4 INSTTTUTIONAL INVESTOR STUDY 2249.

5. Pub. L. No. 94-29, \& 21(e), 89 Stat. 161-62, amending Securities Exchange Act of $1934 \S 28,15$ U.S.C. $\$ 7866$ (1970), is designed to eliminate the fiduciary problems discussed at notes 23-28 infra and accompanying text. The provision reads in full:

(1) No person using the mails, or any means or instrumentality of interstate commerce, in the exercise of investment discretion with respect to an account shall be deemed to have acted unlawfully or to have breached a fiduciary duty under State or Federal law unless expressly provided to the contrary by a law enacted by the Congress or any State subsequent to the date of enactment of the Securities Acts Amendments in 1975 solely by reason of his having caused the account to pay a member of an exchange, broker, or dealer an amount of commission for effecting a securities transaction in excess of the amount of commission another member of an exchange, broker, or dealer would have charged for effecting that transaction, if such person determined in good faith that such amount of commission was reasonable in relation to the value of the brokerage and research services provided by such member, broker, or dealer, 


\section{BACKGROUND OF IndUSTRY PRACTICES}

Before the implementation of negotiated rates, trades on the principal stock exchanges were routinely executed at the fixed fee posted and approved by the particular exchange on which the trade was executed. ${ }^{\circ}$ With respect to such trades, an investment adviser had no reason to choose one broker over another on the basis of price. As a result, the brokerage industry began providing other services, in addition to execution, in order to attract the busmess of investment advisers and institutions generally. ${ }^{7}$ Simce the rules of the New York Stock Exchange

viewed in terms of either that particular transaction or his overall responsibilities with respect to the acconnts as to which he exercises investment discretion. This subsection is exclusive and plenary insofar as conduct is covered by the foregoing, unless otherwise expressly provided by contract: Provided, however, That nothing in this subsection shall be construed to impair or limit the power of the Commission under any other provision of this title or otherwise.

(2) A person exercising investment discretion with respect to an account shall make such disclosure of his policies and practices with respect to commissions that will be paid for effecting securities transactions, at such times and in such manner, as the appropriate regulatory agency, by rule, may prescribe as necessary or appropriate in the public interest or for the protection of investors.

(3) For purposes of this subsection a person provides brokerage and research services insofar as he-

(A) furnishes advice, either directly or througl publications or writings, as to the value of securities, the advisability of investing in, purchasing, or selling securities, and the availability of securities or purchasers or sellers of securities;

(B) furnislies analyses and reports concerning issners, industries, securities, ecouomic factors and trends, portfolio strategy, and the performance of accounts; or

(C) effects securities transactions and performs functions incidental thereto (such as clearance, settlement, and custody) or required in connection therewith by rules of the Coinmission or a self-regulatory organization of which sucl person is a meinber or person associated with a member or in which such person is a participant.

6. The history of fixed commission rates apparently dates back to the Buttonwood Tree Agreement of 1792, whicl provided as follows:

We, the Subscribers, Brokers for the Purchase and Sale of Public Stock, do hereby solemnly promise and pledge ourselves to each other, that we will not buy or sell from this day for any person whatsoever, any kind of Public Stock at a less rate than oue-quarter percent Commission on the Specie value, and that we will give a preference to each other in our Negotiations. In Testimony whereof we have set our hands this 17th day of May, at New York, 1792. SPECIAL STUDY pt. 2, at 295.

This agreement was embodied in stock excliange requirements snch as that found in sections 1 and 2 of article XV of the NYSE Constitution, CCH NYSE Guide TI 170102 (1975), requiring the payment of minimum commissions and establishing rates therefor. For a discussion of the legislative background under the Securities Exchange Act of 1934 relating to fixed commission rates, see Legal Memorandun on Behalf of the NYSE, filed in the Commission Rate Study, [1967-1969 Transfer Binder] CCH FED. SEC. L. REP. II 77,587 (1968). See also Meinoranduin of the United States Department of Justice in the same proceedings [1967-1969 Transfer Binder] CCH FED. SEc. L. ReP. II 77,658 (1969). Finally, see 4 Instrtutional Investors Study 2255, and chapter XI generally, for a complete discussion of execution practices of broker-dealers on and off the exclianges.

7. This problem was first discussed in the Special Study. 
(NYSE) and other exchanges prohibited rebating practices, ${ }^{8}$ a structure of service competition, rather than rate competition, developed. ${ }^{9}$

Among practices which were developed by brokers were: adviser; ${ }^{10}$

(1) Providing analytical and statistical services to an investment

(2) Providing reciprocal business to the investınent adviser (or an affiliate of such adviser) in exchange for such busimess; ${ }^{11}$

(3) Providing research services to the investment adviser; ;2 $^{12}$

(4) Emphasizing the sale of an investment company's shares to obtain that company's brokerage; ${ }^{13}$

8. Section 1 of article XV of the NYSE Constitution prohibits the rebating of commissions among member firms by stating that minimum commissions must be collected and must be "net and free from any rebate, return, discount or allowance made in any shape or manner, or by any method or arrangement, direct or indirect." CCH NYSE GUIDE \I 1701 (1975).

9. Special Study 349-51. See 4 Institutional InVestors Study 2255 et seq.

10. Spectal STUdY pt. 2 , at 312.

11. The practice of providing reciprocal business developed its own mystique over the years. Because the commission rates were fixed and rebates prohibited, a practice of "giving up" a portion of the brokerage at the customer's direction to another broker on generally unrelated trades came into being. This led to such practices as the "fourway ticket" in which a broker executing a trade on behalf of an institutional chent would agree to give up a portion of brokerage on unrelated trades in order to induce the institution to trade with it. The institution could name the broker to whom it wished the unrelated business to be given, or it could obtain the unrelated business itself through an affiliate on a regional exchange, or even through an affiliate who was a NASD (National Association of Securities Dealers) member and not on an exchange. The affiliate of the institution would not perform any real function on the regional exchange other than to accept the reciprocal brokerage as a "clearing" broker and would be so listed on the transaction ticket. If a similar arrangement were made on the other side of the trade, there would be four names on the ticket, the two executing brokers and the two "clearing" brokers. It is this type of "complex and irrational" trading practice that gave the SEC and Congress concern. See 4 INSTrTUtIONAL INVESTOR STUDY 2255.

12. The research services provided were designed to attract brokerage of institutions, which, by the end of 1969 , accounted for more than forty-two percent of the brokerage on the exchanges. As a rcsult, "research boutiques" developed which had limited execttion capabilities, but apparently provided significant, sophisticated research services. See Statement of Chairman Garret, Hearings on S. 249 Before the Subcomm. on Securities of the Senate Comm. on Banking, Housing and Urban Affairs, 94th Cong., 2d Sess. (1975).

13. Over the years, investinent advisers to investment compamies, in analyzing their allocation of brokerage, tended to favor those brokers who were selling a substantial amount of the funds' shares. The SEC, in its Future Structure Statement, directed the NASD to adopt a rule forbidding the allocation of brokerage on the basis of sales. The NASD adopted its "Anti-reciprocal" rule, effective July 15, 1973, Member Notice 7342 , and has recently requested that the SEC reconsider its position in this area. See SEC Investunent Company Act Release No. 8393, [1973-1974 Transfer Binder] CCH FED. SEC. L. REP. \ 79,829 (1974). 
(5) Installing direct wires on the customer's premises to facilitate execution,;

(6) Pricing mutual fund portfolios and calculating daily net asset values. ${ }^{15}$

The practices described in (2) and (4) above eventually were outlawed by SEC and industry rules, ${ }^{18}$ as well as by the results of civil suits, ${ }^{17}$ but the tendency to compete for brokerage on a basis other than straight cost caused the SEC to continue to push for the abandonment of fixed commission rates. ${ }^{18}$

In the meantime, the practice of providing research became an accepted one for brokerage firms. The arrangements made by investment advisers in their contracts with clients reflected the fact that much of the research which would be considered by the adviser in rendering management services would be supplied by brokers in the course of providing execution on trades for the managed account. ${ }^{19}$ Such research might or might not be used directly in rendering advice to the account from which the brokerage was paid. No real conflict of interest was presented under these circumstances, assuming the broker could obtain the best price and otherwise could effect satisfactory execution, since the managing adviser was not paying a "premium" from the assets of the account-the price for the trade was a fixed minimum and would have to be paid in all events. ${ }^{29}$ Correspondingly, the mvestınent adviser

14. 4 INSTITUTIONAL INVESTORS STUdY 2318; SPECIAL STUDY pt. 2, at 308.

15. 4 INSTITUTIONAL INVESTORS STUDY 2318.

16. The customer-directed give-ups were prohibited by rules of the various stock exchanges in late 1968, see, e.g., NYSE CONST. art. XV, \& 1, CCH NYSE GUIDE $\pi 1701$ (1975), at the prodding of the SEC. See note 13 supra on directing brokerage for sales.

17. Moses v. Burgin, 445 F.2d 369 (2d Cir. 1969). In this decision, the Second Circuit did not forbid customer-directed give-ups but concluded that, if an adviser were engaging in such activity, any benefit that it derived from such give-ups had to be shared with the fund. Id. at 382. In fact, the adviser was obligated to inform the investment company that such give-ups were available and that reciprocal business was available so that the investment company might made a decision whether to establish an affiliated brokerage firm to recapture some of its own commissions. Id. at 384 .

18. Throughout this period, the SEC, in correspondence with the NYSE and in hearings, had been urging the adoption of negotiated rates. Eventually, the NYSE adopted negotiated rates with respect to trades in excess of $\$ 300,000$ and, ultimately, on trades below $\$ 2,000$. See NYSE Membership Bulletins, Feb. 12, 1970, and Feb. 19, 1970; SEC Securities Exchange Act Release No. 9148, [1970-1971 Transfer Binder] CCH FED. SEC. L. REP. $\pi 78,029$, at 80,253 (1971). See also In re The Commission Rate Structure of Registered National Securities Exchanges, SEC File No. 4-144 (19681971); In re the Structure, Operation and Regulation of the Securities Markets, SEC File No. 4-147 (1972).

19. Future Structure Statement 5290.

20. SPecial Study pt. 2, at 321. 
established his advisory fee schedule to reflect this fact and did not bargain for a fee which would enable him to buy that research with his own money. ${ }^{21}$ A relatively small amount of researcli services was provided for a specified sum- "liard dollars" paid by the adviser-but most was obtained as an adjunct to the brokerage function through "soft dollars."22

With the advent of negotiated or unfixed rates, however, it is obvious that the adviser would have a choice in directing brokerage to a particular broker. If a brokerage louse provides only execution services, then presumably it will be able to cliarge a lower commission than a broker providing research. Thus, the problem arises: When and how can an adviser conclude that it is proper to pay a higher commission rate (or, in the vernacular, "pay up") in order to obtain research services?

\section{FIDUCIARY LAW IsSUES AND ACCOUNTING DistoRTIONS}

The practice of using a beneficiary's asset to pay for something that is supposed to be provided by the trustee or agent and that, in fact, may not be used to benefit the beneficiary's account at all raises basic common law fiduciary issues. ${ }^{23}$ The general rule is that a fiduciary is under an obligation to act solely in the interests of his beneficiary; in the absence of consent, a fiduciary, whether acting as agent or as trustee, is not entitled to receive a benefit froin the administration of the trust property (or the principal's assets) other than as compensation for services. ${ }^{24}$ This is true whether or not the beneficiary is harmed by the transaction, and is premised on strict liability aimed at preventing conflicts of interest. ${ }^{25}$ The standard applied and the freedom to obtain such benefits may vary soinewhat, depending upon whether there exists an agency or a trust relationship. ${ }^{26}$ It appears that courts have recently been moving away from standards of strict liability in cases where there exists a conflict of interest only, limiting applicability of that doctrine to self-dealing cases. ${ }^{27}$ But even where a court is willing to look behind the

21. FUtURe Structure Statement 5290.

22. Id.

23. 3 A. ScotT, The LAW of TRUSTS $\$ 170.22$ (3d ed. 1967); Restatement of REsTTTUTION $\$ 197$ (1937).

24. Restatement (SecoNd) of Trusts $\S 170(1)$ (1959). See also id., comment 1 at 369 .

25. See, e.g., In re Durston, 297 N.Y. 64, 74 N.E.2d 310 (1947); City Bank Farmers Trust Co. v. Cannon, 291 N.Y. 125, 51 N.E.2d 674 (1943).

26. See note 100 infra and accoinpanying text.

27. See Phelan v. Middle States Oil Corp., 220 F.2d 593 (2d Cir.), cert. denied, 349 U.S. 929 (1955). The claim there was made that one of the receivers of a bankrupt corporation shonld be liable for losses to certain members of a bondholders' com- 
transaction to ascertain its fairness, the trustee or agent must be in a position to demonstrate that the expense was reasonable and was incurred in the best interests of the beneficiary. ${ }^{28}$

These practices also cause some accounting distortions, since sound accounting practice has always required that brokerage costs be treated as costs of purchasing the asset, i.e. as a capital item. ${ }^{29}$ From a tax standpoint, the effect of purchasing research with commission dollars is to increase the basis of the security being purchased by the amount attributable to the cost of research services which are otherwise unrelated to the purchase of the security. The direct purchase of research services, on the other hand, would be treated as an "ordinary" expense of the account and probably would be deductible from current income as such ${ }^{30}$ Since the accounting distortion does not present potential liability problems (presumably the Internal Revenue Service would make no effort to recast any of these transactions), it has generally not been considered so important an issue as the fiduciary problem.

As discussed below, the regulatory sanction of these historical practices in the brokerage and investment advisory industry, particularly the sanction of the SEC, led to a widespread effort to carve out this practice of purchasing research with commission dollars and ensure its continuance, with or without the aid of federal legislation.

\section{REgULATORY AND LEgISLATTVE ACTIVITY}

In the early 1960's, Congress and the SEC began focusing on the problems of fixed commission rates and the troublesome conflict-ofinterest situations engendered by "service competition."31 The Special Study did not focus substantial attention on the issue of fixed versus competitive commission rates, but did first point up the problem of

mittee, because he had a conflict of interest in favoring one plan (sale of assets to a new corporation rather than piecemeal liquidation) because of the possibility that he would become general counsel to the new corporation. Judge Learned Haud concluded that this was not such a conflict of interest as to merit application of strict liability, stating: "[T] The rule does not apply, not only when the putative interest, though in itself strong enough to be an inducement, was too remote, but also when, though not too remote, it was too feeble an inducement to be a determining motive." 220 F.2d at 603.

28. Restatement (SeCOND) of Trusts $\$ 188$ (1959). See notes 25 \& 27 supra.

29. For an institution, research costs would presumably be an ordinary and necessary business expense under section 162(a) of the Internal Revenue Code of 1954. For an individual, such expenses would be deductible under section $212(2)$ as being an expense incurred "for the inanagemeut, conservation, or maintenance of property held for the production of income."

30. INT. REv. CODE OF 1954, § 162(a).

31. SPECIAL STUDY pt. 2, at 301 et seq. 
competition in service rather than in price. ${ }^{32}$

There followed a series of SEC decisions which dealt with the investment adviser's fiduciary obligations with respect to brokerage transactions, ${ }^{33}$ yielding the basic conclusion that the "investment adviser is a fiduciary who is required to serve the interests of his client with undivided loyalty ... [and] one of the basic duties of a fiduciary is the duty to execute securities transactions for chents in such a manner that the clients' total cost or proceeds in each transaction is the most favorable under the circumstances." ${ }^{34}$ Where an investment adviser was somehow executing transactions and obtaining a benefit for itself, by, for example, reciprocal business arrangements, or in the case of investment company advisers, by the allocation of brokerage for sales, the SEC reasoned that such practices were unlawful as inherently involving conflicts of interest, self-dealing, and breach of the fiduciary obligation. ${ }^{35}$

In Delaware Management, the leading case on allocating brokerage to broker-dealers who supply research to the investment adviser, the SEC found that sucl conduct was unlawful where the adviser's client failed to receive the best price on the execution because of such allocation. The SEC held:

The execution of portfolio transactions through broker-dealers who provide research or statistical services to investment advisers of investment compamies is also common practice. Where the investment company, however, receives something less than the best prices and executions solely because the executing broker provides researcli services to

32. Id.

33. Provident Management Corp., SEC Securities Exchange Act Release No. 8790 (Jan. 5, 1970) (brokerage allocated to a broker for assistance to the adviser in selling efforts, no benefit to the investment company found); Consumer-Investor Planning Corp., SEC Securities Exchange Act Release No. 8542, [1967-1969 Transfer Binder] CCH FED. SEC. L. REP. $\mid 77,677$, at 83,525 (1969) (the payments and benefits received by the adviser were not translated into benefits received by the investment company); Kidder Peabody, Inc., SEC Investment Advisers Act Release No. 232, id. T 77,618, at 83,321 (1968); Insurance Securities, Inc., SEC Securities Exchange Act Release No. 8226 (1968). These cases were preceded by the opinion of the SEC in the Delaware Management case. Delaware Management Company, SEC Securities Exchange Act Release No. 8128, [1966-1967 Transfer Binder] CCH FED. SEC. I. REP. II 77,458 (1967). In that case, the adviser, Delaware Management, caused the investment company to sell 202,000 shares of stock at $\$ 13.50$ through a broker-dealer firm, even though it had that same day beeu offered $\$ 14.00$ per share for the same stock. According to the SEC opinion, the "executing broker was selected because it had provided Management [the adviser] with research and statistical services and recommendations with respect to the purchase and sale of portfolio securities for the two Funds."

34. Kidder Peabody, Inc., SEC Investment Advisers Act Release No. 232, [19671969 Transfer Binder] CCH Fed. SEC. L. REP. II 77,618, at 83,321 (1968).

35. See cases cited in note 33 supra. 
the investment adviser, the assets of the investment company are in effect used to enrich the investment adviser at the expense of the fund shareholders. ${ }^{36}$

In the meantime, the NYSE, with prodding from the Commission, established negotiated rates for trades above $\$ 300,000$ and eventually also for trades below $\$ 2,000 .{ }^{37}$ The Institutional Investors Study concluded that the commission rate for institutions was "negotiable" even prior to these actions, but that the fruits of such negotiations benefited the investment adviser rather than the investor. ${ }^{38}$

During 1971 and 1972, Congress and the SEC held hearings on the structure of the securities markets, and in March of 1972, the SEC issued its Future Structure Statement. The then Chairman of the SEC, William J. Casey, said the steps called for in the Statement were

designed to put coinpetition to work for the investor, to move away from reciprocal and rebative practices, to bring transactions into the open and to focus attention where it should be-on where and how to get the best price for a buyer or seller of securities. . . . Mnnvestor confidence will be strengthened as professional attention is reconcentrated on finding the best market, providing information and judgment for the investor, and getting him the best net result, unclouded by considerations relating to the rebating, the redirection and the recapturing of commissions. ${ }^{39}$

Notwithstanding the general language of Chairman Casey's preamble and the general intent of the steps called for in the Future Structure Statement, the Statement itself specifically makes an exception for the practice of using brokerage to purchase research. Thus the Statement

36. Delaware Management Company, SEC Securities Exchange Act Release No. 8128, [1966-1967 Transfer Binder] CCH FED. SEc. L. REP. Tf 77,458, at 82,887 (1967).

37. In SEC Securities Exchange Act Release No. 8324, id. $\pi 77,557$, at 83,182 (1968), the SEC ordered public hearings to be held on whether changes should be made in stock exchange commission rate structures. The same day, then-Commissioner Manuel F. Colren wrote to the president of the NYSE, advising of the public hearings and requesting that the NYSE voluntarily eliminate fixed rates on portions of orders in excess of $\$ 50,000$. Id. at 83,183 . The NYSE countered with alternatives in a letter from its president to the SEC. Id. $\Uparrow 77,585$, at 83,227 . The commission rate structure ultimately adopted for the NYSE was embodied in section 2 of Article XV of the Exchange's Constitution.

38. The fixed minimum stock exchange commission on large orders has led to the growth of complex reciprocal relationships between, on the one hand, institutions (particularly mutual fund managers and banks) and, on the other, broker-dealers. This has had the effect of making commission rates for institutions negotiable but limiting the extent to which the ultimate investor rather than the money manager has benefited from such negotiation. 1 INSTrTutional INvesToR STUdy xxii.

39. Statement by William J. Casey, [Special Studies Transfer Binder] CCH FED. SEC. L. REP. If 74,811, at 65,611 (1972). 
expressly permitted what would become the practice (after introduction of negotiated rates) of paying more for the execution of a trade handled by a broker who was providing research than would be paid another broker for the same trade. ${ }^{40}$ The SEC's justification for this exception was based principally on historical precedent for such practice. The Future Structure Statement says that "it is . . essential that . . . the viability of the process by which research is produced and disseminated not be impaired." 11 The SEC also found support for the payment of research costs with commission dollars in the broker's duty to ensure suitability. ${ }^{42}$ The rationale for this latter argument is not self-evident, but presumably is based on the view that "soft dollar" research practices have led to the wide dissemination of such research among brokers. Because the broker has an obligation to obtain current basic information regarding the security and then evaluate its suitability for a particular client, vigorous enforcement of suitability requirements will naturally result-given unfixed rates-in including in the execution charge an element for "the provision of research services to the extent necessary to comply with these standards." 43 To the knowlege of the author, this argument lias not been put forth by SEC spokesinen since the promulgation of the Future Structure Statement.

The language of the Future Structure Statement led investment advisers to question whether the SEC was shifting its position from that stated in the decisions referred to above. In particular, advisers wondered if the basic statement of the Delaware Management ${ }^{44}$ decision was implictly superseded by the Future Structure Statement. The Commission acted quickly to dispel any doubts on that score in Investment Company Act Release No. $7170,{ }^{45}$ plainly indicating that it had no intention of overriding the holding in the Delaware Management case. Its intention, rather, was only to "extend" that policy in an era of competitive rates. According to the Release, an investunent adviser "should have discretion, in assigning an execution or negotiating the commission to be paid therefor, to consider the full range and quality of a broker's services which benefit the account under management and

40. FUTURE Structure STATEMENT 5290.

41. Id.

42. Id.

43. Id.

44. SEC Securities Exchange Act Release No. 8128 [1966-1967 Transfer Binder] CCH FED. SEC. L. REP. $\{77,458$ (1967). For a summary of this case see note 33 supra.

45. SEC Investment Company Act Release No. 7170, [1971-1972 Transfer Binder] CCH FED. SEC. L. Rep. \7 78,766, at 81,631 (1972). 
need not solicit competitive bids on each transaction." 46 The investment adviser is justified in selecting a particular broker only "if the broker selected provides bona fide investment research or other services which he (the investment adviser) believes are valuable to the beneficiary's interest and if he beheves the broker can properly execute the transaction." 47

The SEC's Release does not elaborate on what would be considered "bona fide" research and other services. ${ }^{48}$ of course, the Delaware Management case itself involves more than the single issue of selecting a broker on the basis of research services; the adviser chose the broker supplying such research at an execution price of $\$ 13.50$ per share, even though it had a firm bid of $\$ 14.00$ per share from another broker. The loss to the managed account was $\$ 101,000$. . $^{49}$

When legislative activity in the Senate and House during 1972 and $1973,{ }^{50}$ coupled with SEC activity, ${ }^{51}$ made it evident that unfixed rates would becoine a reality, the voices of concern among industry groupsbrokerage firms as well as investment advisers, and banks-accelerated inarkedly. During the Ninety-third Congress, these groups lobbied in support of legislative proposals which would establish a federal law on "paying up" for research. House Bill 5050, ${ }^{52}$ which was reported favorably out of the House Interstate and Foreign Commerce Committee, included a proposed amendment to the Investment Advisers Act provid-

46. Id. at 81,632 (emphasis added).

47. $1 d$.

48. The release goes on to state that the "determinative factor is whether the transaction represents the best qualitative execution for the beneficiary." $I d$. The conclusion in the release is not inconsistent with the Future Structure Statement if the Delaware Management holding is viewed in terms of "best price" with respect to the execution price, rather than "best price" with respect to the brokerage commission charged, assuming that the higher commission rate is for services which are of some benefit to the account.

49. See note 33 supra.

50. Committees of both the Senate and House held hearings beginning in 1971 and issued reports in 1972 calling for the end of fixed commission rates. Subcomm. ON Securities of the Senate Comm. on Banking, Housing and Urban affairs, 92D Cong., 2d Sess., Securrtres Industry Study (Comm. Print 1972); Subcomm. ON Commerce and Finance of the House Comm. on INTERSTate and Foreign Commerce, Securities Industry STudy, H.R. Doc. No. 1519, 92d Cong., 2d Sess. (1972). House Bill 5050, 93d Cong., 2d Sess. (1974), was favorably reported out of the House Committee in November of 1974. A companion bill, S. 470, had passed the Senate earlier. Both bills contained provisions putting an end to fixed commission rates. Intensive lobbying efforts, particularly by the NYSE, led to the demise of House Bill 5050 in the House. See BNA SEc. REg. \& L. REP., No. 282, at 1 (Dec. 18, 1974).

51. Some of the SEC activities are mentioned in note 18 supra.

52. H.R. 5050, 93d Cong., 2d Sess. (1974). 
ing that an investment adviser ${ }^{53}$ would not be deemed to have breached a fiduciary duty solely by paying a higher commission for brokerage services than that charged by some other broker, so long as "such commission is the result of such investment adviser or person having reasonably taken into account the quality and reliability of the brokerage services, including the availability and value of research or execution services." 54 The proposed amendment provided that it could be overridden by express federal or state legislation but was otherwise intended to pre-empt such law, ${ }^{55}$ and would have required appropriate disclosure to clients. The language of the Committee Report on House Bill 5050 was designed to establisl a standard of "reasonable business judgment" for the fiduciary investment adviser.

Even the strong, all-encompassing language of this proposed amendment proved unsatisfactory to a number of institutions. ${ }^{56}$ In the first place, according to the Committee Report, an investment adviser was not being "given unqualified license to use the assets of one beneficiary to compensate for research which inay inure to the benefit of another." ${ }^{27}$ Indeed, the clear implication of the Report was that, in most cases, a one-to-one relationship had to be demonstrated, i.e. the adviser had to demonstrate that the research acquired from the broker would be used for the direct benefit of the trading account. ${ }^{58}$ Such a requirement is clearly impractical both from a recording standpoint and from a business transaction standpoint, since "soft dollar" research is rarely (if ever) exclianged for brokerage commissions at the time of execution. Normally, institutions calculate the benefit of a particular research relationship with a broker at the end of a year and then determine low much brokerage will be allocated to that broker in the upcoming year. ${ }^{58}$

53. The amendment also protected one who would be an investment adviser but for the exemption in section 202(a) (11) of the Act (i.e. bank trust departments).

54. H.R. 5050, 93d Cong., 2d Sess. \$ 604 (1974).

55. Id. House Report No. 93-1476 made it clear that the intent of the provision was to override existing state and federal law. The Report states:

By way of emphasis, the committee should point out that it does intend by this language to preempt and overturn common law principles of fiduciary conduct or any interpretation of state or federal law which would expose fiduciaries to liability solely on the basis that they have failed to obtain the lowest commission cost available. H.R. REP. No. 1476, 93d Cong., 2d Sess. (1974), in CCH FED. SEC. L. REP. (No. 561) at 94 (extra ed., Nov. 25, 1974).

56. See Securities WeEK, Feb. 17, 1975, at 2.

57. H.R. REP. No. 1476, supra note 55, at 93.

58. See id.

59. The following description appears in the Institutional Investors Study:

A senior vice-president of one of the largest life insurance companies explained that at the beginning of each year his company prepared a budget detailing the amonnt of commissions each brokerage firm shonld receive in return for the research to be provided. Because most of the commissions paid by this 
As these activities were taking place, several other developments heightened institutional concern about the "soft dollar" issue. Congress had been laboring for some time with a pension reform bill, and in October of 1974 it enacted the Employee Retirement Income Security Act of $1974 .^{60}$ That bill imposes, under provisions administered by the Department of Labor, a new set of fiduciary responsibilities affecting all persons dealing with employee benefit plans, including investment advisers. ${ }^{01}$

Sections 404 and 406 of the Act impose an obligation on the fiduciary to act only for the "exclusive benefit" of the participants under the plan, and define a "prohibited transaction" as any use of the assets of the plan "by or for the benefit of any party in interest." ${ }^{2} 2$ The investment manager, whether acting as a trustee or simply as the investment adviser, would by definition be a party in interest. Therefore, absent some legislative exception, the use of assets of a pension fund to purchase research (through commission dollars) would be in violation of these provisions, since the research would be used by the party in interest (investunent adviser) in managing the assets of the plan (and conceivably in inanaging other accounts) ${ }^{63}$

In addition, the Comptroller of the Currency was giving little comfort to institutions and their advisers on the "soft dollar" issue. Initially, the Comptroller's office announced that it was drafting special instructions for its bank examiners to assist them in ascertaining whether banks were obtaining best execution and the extent to which brokerage was being used to pay for research. ${ }^{64}$ These drafting plans were later

company went to the research firms, at the end of a few months the budgeted commissions were already paid. Rather than pay the additional commissions to other firms from whom this company received no research or unsatisfactory research, it continued to pay commissions to the same research firms, basically in the same ratio as the budgeted amounts. 4 INSTTTUTIONAL INVESTORS STUDY 2263-64.

See notes 81-84 infra and accompanying text.

60. Pub. L. No. 93-406, 88 Stat. 829 (Sept. 2, 1974).

61. Id. $\$ \$ 401$ et seq.

62. By definition, an "investment manager" is a fiduciary to a pension plan, whether or not named as such. Id. $\S 3(38)$. An investment manager is a "party in interest" as is anyone "providing services to such plan." Id. § 3(14).

63. The Securities Industry Association, prior to enactment of the Securities Acts Amendments of 1975, asked the Departments of Labor and Treasury to adopt regulations providing that, in determining whether a payment for execution which includes research is as favorable as an arms-length transaction with an unrelated party, "no comparison should be made with the fee which might have been paid to another brokerdealer in similar circumstances." BNA SEC. REo. L. REP. No. 295, at A-8 to -9 (Mar. 26, 1975).

64. Securities WeEK, Apr. 29, 1974, at 3. 
indefinitely postponed, ${ }^{65}$ but in correspondence with one national bank, the Coniptroller's office signaled a concern over "paying up" for research after May 1, the effective date of rule 19b-3. The Comptroller concurred in an arrangement by that bank to pay for research with commission dollars on third-market trades, provided that best execution was obtained and "the accounts for which the transactions are made receive the primary benefit froni the services being purchased."'68 The Comptroller's letter points out, however, that on the establishment of unfixed commission rates, the payment of higher fees for services could be a breach of trust. ${ }^{67}$ Even a liberal policy by the Coinptroller might not have resolved the issue, simce trust departments of national banks could have felt bound to stricter standards in the common law of trusts.

\section{SEcurities ACts Amendments of 1975}

Early in the Ninety-fourth Congress, bills were introduced in the House (H.R. 10) ${ }^{68}$ and the Senate (S. 249) ${ }^{68}$ which were identical to the House and Senate bills in the Ninety-third Congress, designed to put an end to fixed commission rates, but which also contained rehef on the "payimg up" question. As described above, however, these relief provisions were unsatisfactory; ${ }^{70}$ upon the SEC's announcement of rule 19b3 , therefore, there were increased lobbying efforts anned at broadening the scope and application of the protective provisions in the House and Senate bills. ${ }^{71}$ Just prior to the Senate hearings on Senate Bill 249, Senator Harrison A. Williams of New Jersey introduced an amendment to that bill designed to give complete comfort to all advisers and trustees on the "paying up" issue. ${ }^{72}$ This "Paying-up Amendment" was included in section 21 of the Securities Acts Amendnients of 1975, ${ }^{73}$ amending section 28 of the Securities Exchange Act of 1934.

The language of the ainendnient covers banks, as well as investment advisers regulated by the Securities and Exchange Commission, and provides that:

No person . . . in the exercise of investment discretion with respect to an account shall be deemed to have acted unlawfully or to have

65. Id., July 29,1974 , at 3 .

66. Id., Dec. 9, 1974, at 2.

67. Id.

68. H.R. 10, 94th Cong., 1st Sess. (1975).

69. S. 249, 94th Cong., 1st Sess. (1975).

70. See notes 56-59 supra and accompanying text.

71. SecurTties WeEK, Feb. 24, 1975, at 5.

72. Amend., S. 249, 94th Cong., 1st Sess. (Feb. 19, 1975).

73. Pub. L. No. 94-29 \& 21(e) (1), 89 Stat. 161 (1975). 
breached a fiduciary duty under State or Federal law unless expressly provided to the contrary by a law enacted by the Congress or any State subsequent to the date of enactment of the Securities Acts Amendments in 1975 solely by reason of his having caused the account to pay a member of an exchange, broker, or dealer an amount of commission for effccting a securities transaction in excess of the amount of commission another member of an exchange, broker, or dealer would have charged for effecting that transaction, if such person determined in good faith that such amount of commission was reasonable in relation to the value of the brokerage and research services provided by such nember, broker, or dealer, viewed in terms of either that particular transaction or his overall responsibilities with respect to the accounts as to which he exercises investment discretion. This subsection is exclusive and plenary insofar as conduct is covered by the foregoing, unless otherwise expressly provided by contract: Provided, however, That nothing in this subsection shall be construed to impair or limit the power of the Coinmission under any other provision of this title or otherwise. ${ }^{\mathbf{7 4}}$

The key to the amendment is that it enables a manager to purchase research with commission dollars, without having to demonstrate that particular research was purchased with particular commission dollars to benefit the particular account out of which the commissions were paid. Instead, the manager is safe so long as he can demonstrate that the commission was reasonable im relation to the value of the brokerage and research services provided, viewed in terms of his overall responsibilities for all accounts under his management.

The subsection "is exclusive and plenary," and was intended by its sponsor to "expand the scope of these provisions [in Senate Bill 249 as introduced] to all imvestment managers while clarifying their application." ${ }^{\text {"76 }}$ Commission Chairman Ray Garret, testifying at the hearings on Senate Bill 249, based the SEC's support for the legislation on the reasoning that the federal government had created the "soft dollar" problem by moving to negotiated rates and was therefore obliged to resolve the problem. ${ }^{77} \mathrm{He}$ acknowledged that fixed rates had created a system under which broker-dealers, unable to compete for brokerage on the basis of price, competed on the basis of services rendered for the fixed price. ${ }^{78}$ The institution of unfixed rates and the consequent unbun-

74. Id.

75. $I d$.

76. Opening Remarks of Senator Williams, Hearings on S. 249, "Securities Acts Amendments of 1975" Before the Senate Banking Subcomm. on Securities, 94th Cong., 1st Sess. (1975); BNA Daily Report for Executives, Feb. 19, 1975, at B-1.

77. Hearings on S. 249, supra note 76 , at 255 (statement of SEC Chairman Garret).

78. Id. at 254-55, 
dling of prices for various services would cause problems for both the broker-dealer and the institutional money manager, absent legislation making it clear that such arrangements could continue. Interestingly, the Chairman's statement describes the problems of brokers who "have relied heavily on research (rather than superior execution, ability to position, access to attractive blocks and purcliasers . . .)."79 The statement highlights the definitional problems in the area, since the SEC (and Congress) las consistently maintained that, even if the adviser is perinitted to "pay up" for research, he must still obtain "best execution." 80

The statement does acknowledge the industry practice of purchasing researcl with commission dollars, pointing out that the "compensating commission business [to the broker supplying research] need have no relation to the subject matter of the research," and that "the schedule for allocating brokerage has often been on an annual basis, after the manager has reviewed the research and other services rendered during the past year by all of the dozens or even lundreds of firms with which he lias done business." ${ }^{11}$ These points make it clear that the type of provision in Senate Bill 249, without the amendment, would not provide the protection needed by investment inanagers.

Thus, the SEC's primary reason for supporting the protective provision on the subject ${ }^{82}$ was that the historical pattern of providing research for commission dollars las forced brokers and investment managers to structure their businesses and fees in a certain way. Altering that pattern at this point would be unduly harmful to both segments

79. Id. at 255 (emphasis added).

One of the economic anomalies of fixed commission rates is that they have covered a multitude of services and presented a multitude of opportunities, indeed, temptations. When broker-dealers cannot compete on the price of their basic services, they compete on services they can render for the price. When money managers cannot vary the price they pay for basic services, they use the payments to obtain other services. Id.

80. It may be, ironically, that unfixed rates are increasing investors' costs rather than decreasing them. One study has suggested that trades made at discounted commissions are often poorly executed, so that the execution price is unfavorable enough to offset or outweigh the saving on the commission. Elia, Heard on the Street, Wall Street J., Nov. 7, 1975, at 39, col. 3. So far as appears in this report of the study, there is no reason to suppose that the negotiation of commission rates is a cause of the poor execution. It may well be, however, that investors are selecting brokers on the basis of commission rates, and paying lower commissions for worse service. This seems not to be required, in view of the statutory reference to "the exercise of . . . business discretion," see notes 85-88 infra and accompanying text, and in view of the flexible requirement for a good faith determination that the commission charged is reasonable, see notes 89100 infra.

81. Id.

82. See text accompanying notes $39-43$ supra. 
of the securities industry. ${ }^{83}$ Presumably, the Commission was also influenced by the fact that two years earlier, in the Future Structure Statement, it had sanctioned the continued payment for research with coinmission dollars-after the establishment of unfixed rates. Industry representatives einphasized their reliance on the Statement in structuring business arrangeinents in the years which followed the Statement. ${ }^{84}$

\section{APPLICATION OF THE AMENDMENT}

In order for the provisions of the Williams amendment to apply, a number of criteria must be met:

(1) The adviser must be taking the action (paying commission dollars for research) "in the exercise of his investment discretion with respect to an account." The importance of this criterion lies in its limitation on the adviser to restrict payment of a higher brokerage commission to those cases in which the adviser's decision to make the higher payment is linked to an assessment of his overall advisory responsibilities. A manager's choice to "pay up" on a particular trade should coincide with his conclusion that the researcli provided by the broker is

83. In speaking of the investment adviser's problem, Chairman Garret stated:

In establishing their money-management arrangements, whether as trustee, pension fund manager, mutual fund manager, or what not, they have known and presumably relied on the fact that portfolio activity at fixed rates was going to result in broker-dealers' tendering them "free" research. What the brokerdealer typically expects for his research is commission business. Id.

84. One broker-dealer, William D. Witter, Inc., in a submission to the SEC during 1974, stated as follows:

In the case of our firm, as a result of the Commission's pronouncements regarding broker-produced investment research, our employees and owners more than doubled their invested equity capital in the firm. Similarly, our research staff was more than doubled as was our research payroll. Fimally, alternative capital employment and business diversification plans were abandoned. SECURITIES WEER, Dec. 9, 1974, at 6.

See Combined Statement of Baker, Weeks \& Co., Inc.; Donaldson, Lufkin \& Jenrette Securities Corp.; Mitchell Hutchins, Inc.; and Oppenheiner \& Co., Hearings on S. 249, supra note 76, at 329-31. In addition to supporting the amendment, this statement lists four reasons for continuing the present system of compensating brokers for research services.

Research is a result-oriented activity-institutions can pay for the product after the fact, thus assuring that they have the time to evaluate its worth to them.

Institutions receive services of more organizations since ease of allocation of business encourages more brokers to compete for the business. This, in turn, encourages innovation and improving quality since the customer can easily assign payment from one firm to another.

Small and medium-sized institutions, by consolidating their business, can command the same service and access to information as large organizations, thus making them counpetitive. It would not be efficient or feasible for each of these managers to seek to duplicate the research available through brokers.

Organizations have no contractual liability, a big leveling factor among institutions of varying size. H.R. RzP. No. 94-123, 94th Cong., 1st Sess. 95 (1975). 
beneficial to the carrying out of his total advisory function. The language, "in the exercise of investment discretion with respect to an account," apparently indicates that the research must, at least indirectly, benefit the account froin which the commission is paid. ${ }^{85}$

This analysis is consistent with the Congressional reports, which provide clear support for the investment adviser's right to "pay up" for research, though limiting the protection to "bona fide" payments. The House Committee on Interstate and Foreign Commerce, in its report accompanying House Bill 4111, stated:

[A] plaintiff does not carry his burden of proof nor state a cause of action by merely showing that a defendant fiduciary paid a commission higher than he could have obtained had he used a different broker. Rather, a challenge to fiduciary conduct must be premised on the basis that a fiduciary has failed to use reasonable business judgment in selecting his broker and valuing the services rendered. It is, of course, expected that money managers paying brokers an amount which is based upon the quality and reliability of the broker's services including the availability and value of research, would stand ready and be required to denonstrate that such expenditures were bona fide. ${ }^{86}$

The report of the House Committee makes it clear that the applicable test is a "business judgment rule," under which the investment manager uses his "best judgment in selecting a broker whom [sic] he believes is providing valuable services for his beneficiaries, and pays him what the fiduciary considers to be a reasonable fee for these services." For exainple, if an investment adviser has accounts under management-in trust or otherwise-which could never benefit froin the type of research generated by commission dollars (because of restrictions imposed on investment discretion, or for whatever reason), the payinent of commission dollars from that account for research services would not be warranted. As a practical matter, this means that advisers will be obligated to characterize accounts when established as either being or not being the types of accounts which reasonably would benefit from the research provided by brokers through whom the adviser generally executes its trades. Presumably, the instances would be rare in which a particular account would be designated as one which would not

85. Other language in the amendment, and in the committee reports, qualifies this interpretation. See text accompanying notes $89-91$ infra.

86. H.R. REP. No. 94-123, 94th Cong., 1st Sess. 95 (1975) (emphasis added).

87. Id. Section 503 of House Bill 4111 was almost identical to section 21 of the final bill. The House Committee Report stated that the Committee did not believe that a fiduciary would necessarily be liable under general fiduciary principles for "paying up" for research but that section 503 was intended to clarify the law in this respect. 
properly support "paying up" for research. ${ }^{88}$ This requirement also should mean that the investment manager will have to review accounts periodically to determine the continued propriety of "paying up" from each account.

(2) There must be a good faith determination by the adviser that the amount of the commission is reasonable in relation to the value of brokerage and research services provided, "viewed in terms of either that particular transaction or his overall responsibilities with respect to the accounts as to which he exercises investment discretion."

This is the central provision in the proposed amendment designed to enable the adviser to justify "paying up" from a particular account so long as the commission is reasonable in relation to all accounts nnanaged by the adviser. It eliminates the need for a direct correlation of benefits with commission dollars paid out of a particular account, at least in evaluating whether the commission paid was "reasonable." 89

The Senate Report makes it clear that such direct correlation is not a prerequisite to a finding of reasonableness:

This standard of "reasonableness" does not require that the value of research and brokerage services be imputed to any specific account; rather, reasonableness is to be measured in view either of that particular transaction or of the fiduciary's overall responsibilities with respect to the account over which he exercises investment discretion. It is thus unnecessary for the money manager to show that specific services benefited specific accounts. ${ }^{90}$

When coupled with the language described in (1) above, however, the provision does not completely eliminate the adviser's obligation to ensure that some benefit ultimately flows to the account from the general practice of "paying up." 1 This would seem to be the easier of the two tests to administer, smce it can be evaluated both on the basis of a particular broker's execution capabilities and research services generally and on the basis of the price of such services compared to prices of other brokers providing similar services and compared to prices of brokers providing "bare bones" execution services. Unfortunately, the

88. On the assumption that most advisory accounts will require some continuing general analysis and oversight with respect to investment decisions and portfolio changes, and on the further assumption that an investment manager will only deal with those broker-dealers supplying quality research commensurate with the additional cost required, it would seem logical to conclude that most accounts would ultimately obtaim some beuefit from access to such research.

89. This language should be construed to limit the problematic phrase "with respect to an account," mentioned in the text accompanying note 85 supra.

90. S. ReP. No. 75, 94th Cong., 1st Sess. 70 (1975).

91. See note 85 supra and accoinpanying text. 
practice since May 1 appears to give little weight to the overall abilities of a particular broker; in most cases, trades have been given to those brokers charging the smallest commission for a particular stock trade. ${ }^{92}$ "Deep-discounters" have been offering from fifty percent to seventy-five percent off the old fixed NYSE rates for trades, and thirty percent to forty percent discounts seein to be common. ${ }^{93}$ Thus, the battle to date has been substantially for price, rather than for execution capabilities and research. ${ }^{94}$ As the discounts begin to stabilize, however, and the initial trauma of the unfixed rates wears off, it can be expected that "paying up" for valid research services will be more prevalent, and advisers will be concerned with compliance with this test. ${ }^{95}$

The remaining question under this requirement concerns the types of research that can be paid for with commission dollars. The view has been expressed at the Commission that it should establisli a minimum standard as to what constitutes bona fide research and other services, and should permit payment only for highly sophisticated materials. ${ }^{96}$ For example, such a rule would preclude the adviser from purchasing magazime and newspaper subscriptions or other "basic elements" of research service. There appears to be some concern among SEC staff members that this provision will be abused in the absence of such a rule, and advisers will have their office furniture and similar overhead items paid for with commission dollars. ${ }^{97}$ This concern seems unwar-

92. SeCURTIIES WeEK, June 23, 1975, at 7.

93. Id., July 7,1975 , at 4 . One observer estimates that "brokerage fees paid by pension funds, bank trust departments and other institutions that dominate the stock market have dropped by about 30\% . . . Bacon, Changing of the Guard at SEC, Wall Street J., Oct. 28, 1975, at 22, col. 4. The Securities Industry Association reports that commission reductions average at least thirty-five percent. Elia, supra note 80.

94. See Games People Are Playing with Fully Negotiated Rates, Institumonal INvestor Magazine, July 30, 1975, at 29. This battle has had casualties, including deaths among research-oriented brokerage firms. See, e.g., Wall Street J., Oct. 6, 1975, at 15, col. 2; Bacon, supra note 93.

95. One article reports that, despite the unfixed rates and the reduced frequency of "paying up," brokerage firms are continuing to add analysts to their staffs. SEcuRIIIES WeER, July 14, 1975, at 4. Donaldson, Lufkin \& Jenrette is reputed to have initiated cost analyses discussions with each of its clients, looking toward the establishment of a cost-justified relationship with its clients. This approach could be helpful to fiduciaries in establishing the "reasonableness" of their own relationship with a particular broker. See id., June 16,1975 , at 1. One member firm is planning to offer a computer research service which will monitor broker performance by developing "ratings which emphasize the institutional traders' criteria for best execution and best price." Id., Apr. 7,1975 , at 3 .

96. Allan Mostoff, Director of the Division of Investment Management Regulation of the SEC, has publicly stated that the SEC will not permit investment companies to purchase certain kinds of services wilh "soft dollars." Such services would include newspapers, periodicals, office furniture, and rent. Id., May 19, 1975, at 14.

97. Id. 
ranted in view of the definition of "brokerage and research services" in the amendment, which states as follows:

(3) For purposes of this subsection a person provides brokerage and research services insofar as he-

(A) furnishes advice, either directly or through publications or writings, as to the value of securities, the advisability of investing in, purchasing, or selling securities, and the availability of securities or purchasers or sellers of securities;

(B) furnishes analyses and reports concerning issuers, industries, securities, economic factors and trends, portfolio strategy and the performance of accounts; or

(C) effects securities transactions and perfornus functions incidental thereto (such as clearance, settlement, and custody) or required in connection therewith by rules of the Commission or a self-regulatory organization of which such a person is a member or person associated with a member or in which sucli a person is a participant.98

The Senate Report makes it clear that the bill intends that "brokerage and research services" be broadly defined:

The definition of brokerage and research services is intended to comprehend the subject matter in the broadest terms, subject always to the good faith standard in Subsection (e)(1). Thus, for example, the reference to economic factors and trends would subsume political factors which may have economic implications which nnay in turn liave inplications in terms of the securities markets as a whole or in terms of the past, present, or future values of individual securities or groups of securities. Similarly, computer analyses of securities portfolios would also be covered. Thus, the touchstone for determining when a service is within or without the definition in Section 28(e)(3) is whether it provides lawful and appropriate assistance to the money manager in carrying out his responsibilities. ${ }^{99}$

The author submits that the SEC would be well advised not to formulate such a rule defining research but, instead, to leave it to the disclosure requirenents (discussed below) and court tests of reasonableness to provide the policing mechanisnis. The SEC should not permit itself to wander into the thicket of announcing-by rule, no-action letter, or otherwise-what is or is not a proper type of research to be purchased with commission dollars, but rather should limit itself to bringing enforcenent actions where an adviser is paying commission dollars to obtain services which fall outside the scope of the three categories in the bill. It should be clear enough to a prudent adviser that

98. Pub. L. No. 94-29, § 21(e) (3), 89 Stat. 161-62 (June 4, 1975).

99. S. REP. No. 75, 94th Cong., 1st Sess. 71 (1975). 
he cannot use brokerage to purchase secretarial services or a subscription to The Wall Street Journal. Moreover, the language of the amendment makes it clear that for research to be justified it must be "provided" by the broker. The author submits that the meaning of this is that the broker himself must, in some significant way, be involved in the development of the research material or services.

There would appear to be some difference as to what is "reasonable" in this area, depending upon whether an adviser is acting as trustee or as agent. Generally, a trustee may not incur expenses on behalf of a trust for items that a beneficiary could reasonably expect to be provided by the trustee. ${ }^{100}$ Thus, if a trustee holds itself out as an investinent manager, it probably could not "pay up" for other than sophisticated research services. On the other hand, an argument can be made that if an agent, dealing at arm's length with a principal who is able to fend for himself, contracts with the principal for payment from the account of commission dollars for research services, the scope of those services should be left to the contracting parties. Whatever his capacity, it is clear that any adviser who "pays up" must be obtaining beneficial services for his accounts, and the imcremental cost of such services (in the form of increased brokerage commissions) must be reasonable.

There remains the problem of devising methods for recording the adviser's conclusions that "paying up" on a particular trade is justifiable. In general, advisers should be encouraged to develop systems for evaluating the services of brokers on a periodic basis. ${ }^{101}$

One industry source has indicated that it has already prepared forms for use by its traders to record its justification for using a particular broker. ${ }^{102}$ The forms would reflect the commission rate, the broker's capital, the broker's clearing capabilities (the chance of "fails"), the ability to position, and research. ${ }^{103}$ Such forms would help resolve the larger issue of whether best execution was, in fact, obtained. ${ }^{104}$ Because of their complexity, these forns may prove unworka-

100. See notes 24-28 supra and accompanying text.

101. One brokerage firm, William $\mathrm{D}$. Witter, has prepared a legal memorandum it is circulating among clients which is designed to ease the fears of imstitutions on "paying up." The memorandum lists procedures which shonld be adopted by advisers, such as the following:

(1) development of a quantity, source, and price rationale which would cover such elements as diversity, source, and amount.

(2) a commission allocation system between accounts so that one account does not bear a disproportionate amount of the research cost. SEcurrIIES WEEK, July 7, 1975, at 9 .

102. Id., Feb. 10, 1975, at 7.

103. Id.

104. Id. 
ble in the ordinary day of an active trading department, and perhaps should be replaced with something which would simply reflect the nature of the account for which the execution is to be made, the commission rate, and the trader's general evaluation of the execution capability of a particular broker on a trade of specified size. If the standard of reasonableness with respect to the benefit to the account is stated in terms of a reasonably anticipated present or future benefit, and the account is one designated as being an account which could reasonably be expected to benefit from research supplied by brokers, the trader should be permitted to make a decision on that basis. The emphasis should be on review of accounts, review of commission rates generally, review of benefits to accounts (use of research supplied by a particular broker), and full disclosure as discussed below.

(3) Disclosure must be made in accordance with regulations established by the appropriate regulatory authority. The prospectuses of most registered investment companies continually selling their shares (i.e., mutual funds) disclose the factors considered by an investment adviser in allocating brokerage. Typically included is a reference to consideration of research services provided by brokers, so long as "best execution" is obtained. In a number of recent prospectuses, there is langnage which anticipates negotiated commission rates. Roughly ninety percent of the funds, according to a recent study, have not mentioned the issue of "paying up" in their prospectuses. ${ }^{105}$ According to the same analysis, at least two large fund complexes have disclosed these facts. ${ }^{106}$ The SEC staff has requested that funds disclose the effect of "paying up" on expenses of the fund and the adviser; the staff has also encouraged the funds to define the types of services they will purchase with soft dollars. ${ }^{107}$ One mutual fund has adopted a substantial disclosure discussion which explains that the adviser will use brokerage firms that supply research which may be valuable to the adviser in rendering advice to its

105. Id., June 30 , 1975, at 8.

106. $I d$.

107. Id. The SEC staff originally issued guidelines telling mutual funds how they should disclose brokerage payments, id., Aug. 4, 1975, at 5, but those guidelines were sharply criticized by Senator Williams, the author of the Paying-up Amendment, who found that they undermined the amendment and disregarded its imtent, id. at 1, 5-6. Shortly after Seuator Williams voiced his criticisms the guidelines were withdrawn. Id., Sept. 22, 1975, at 1. The new staff guideline "simply asks a mutual fund to describe its practices and policies on paying for brokerage and services as defined in the amendments." Id. Senator Williams sees this change as a partial resolution of the problem, but has urged the Commission to ensure that any "incorrect views" communicated by the earlier guidelines are dispelled, and to "adopt disclosure rules as envisioned by the Congress." Id., Oct. 20, 1975, at 2, $2 \mathrm{a}$. 
other accounts, but not likely to reduce the adviser's expenses. ${ }^{108}$ According to the fund prospectus, typical research services would include

studies made by investment analysts or economists relating either to the past record of and future outlook for companies and the industries in which they operate, or to national and worldwide economic conditions, monetary conditions and trends in investors' sentiment, and the relationship of these factors to the securities market. In addition, such analysts may be available for regular consultation . . . . 109

Presumably, an annual recitation of the adviser's general practice in this regard should be satisfactory, since the adviser will be obliged to justify the benefits to the fund from such practices in the course of negotiating the advisory fee..$^{110}$

108. Id., June 30,1975 , at 8.

109. Id.

110. Section 15(c) of the Investment Company Act of 1940 requires mutual fund disinterested directors to "request and evaluate ... such information as may reasonably be necessary to evaluate the terms of any contract whereby a person undertakes regularly to serve or act as investment adviser of such company." 15 U.S.C. \& 80a-15(c) (1970).

It may be noted that in the absence of a legislative exception, several unique problems face investment companies, or "mutual funds," registered under the Investment Company Act of 1940, id. $\S 802$. That act requires that a written contract between the adviser and the investment company describe precisely "all compensation to be paid thereunder." Id. $\$ 802-15$ (a)(1). The position has been taken by some courts, see Lutz v. Boas, 171 A.2d 381 (Del. Chanc. Ct. 1961), and by the Commission, see Managed Funds, Inc., 39 S.E.C. 313 (1959); Continental Inv. Corp., SEC Investment Company Act Release No. 7417 [1972-1973 Transfer Binder] CCH FED. SEc. L. REP. I 79,024 at 82,231 (1972); and cases cited in note 33 supra, that an adviser's receipt of a benefit from dealing with the assets of the fund (such as using brokerage to reward sales of fund shares) constitutes compensation not described in the contract, making the contract void under section 47 of the Act. It could be argued that using brokerage and commission dollars to obtain research for which the adviser would otherwise have to pay is a means of receiving compensation not referred to in the contract. A similar potential problem arises under section 17 (e) (1) of the Act, which makes it unlawful for any affiliate of a fund, acting as agent for the fund, to accept compensation for the purchase or sale of property to or from the fund, except in the course of business as underwriter or broker. 15 U.S.C. $\$ 802-17$ (e)(1) (1970). The adviser directing a fund's brokerage typically does act as an agent. If the receipt of research were deemed to be additional compensation, the adviser would be in violation of the Act. In both sorts of cases, however, any conclusion that the research was compensation would seem strained, and inconsistent with the Commission's general support for "paying up." Even without specific legislation it would be better to permit the adviser to demonstrate that the investment company received best execution, and either has benefited or can reasonably expect to benefit from the research supplied. In those circumstances, the research is not compensation to the adviser, and the commission payment with the "paying up" for research is a legitimate business expense of the investment company. This is clearly distinguishable from the use of brokerage to generate sales of fund shares, an important distmction since there is at least some serious question at the Commission whether such increased sales benefit anyone other than the adviser. See Provident Management Corp., SEC Securities Exchange Act Release No. 8790 (Jan. 5, 1970). 
(4) Persons exercising investment discretion with respect to an account must make such disclosures of their policies and practices with respect to commissions paid for effecting securities transactions as are prescribed by regulation.

In the case of individual and group accounts, other than inutual funds, the SEC recently proposed to adopt a new rule 206(4)-4 under the Investment Advisers Act of 1940 which would require that investment advisers provide clients with written disclosure statements containing certain specified information. ${ }^{111}$ Under the proposed rule, investment advisers would be required to furnish their clients, forty-eight hours prior to entering into, extending, or renewing any investment advisory contract, a stateinent reflecting "the general source or sources of information used by the investment adviser as the basis for any investment advice rendered to clients and the inethods employed by the

A different sort of potential problem exists where one mvestment adviser serves more than one mutual fund, and allocates brokerage from one fund to a broker supplying research which might inure to the beuefit of another fund. Rule 17d-1 under section 17(d) of the Act prohibits any "joint enterprise or joint arraugement" between a registered investment company and any affiliated company, or affiliate of an affiliate, without specific Commission approval. 17 C.F.R. $\$ 270.17 \mathrm{~d}-1$ (1974). The investment adviser would be an affiliate of all the managed funds, including the one paying the brokerage and the one receiving the benefit, so the funds would be affiliates of affiliates. If the inter-fund benefits were deemed to be a "joint enterprise or joint arrangement," special approval would be required. It would seem inappropriate, however, for this to be treated as a "joint enterprise or joint arrangement" unless the adviser soinehow coordinated cominission payment for research among the funds for the purpose of achieving soine benefit both for itself and for each fund in the complex. Unfortunately, these provisions are far from clear, and the Commission staff takes a very broad view of the rule and of what constitutes a "joint enterprise or joint arrangement." See Staff Reply issued to United States Trust Co. of New York, [1972-1973 Transfer Binder] CCH FED. SEC. L. REP. II 78,814, at 81,796 (1972).

A final problem area was, and still may be, the common state law provisions that require investment advisers to reimburse the investment company for expenses of the company in excess of a specified amount, usually stated as one percent or one and a half percent of net asset value. See, e.g., California Regs. $\$ 260.140 .84,1 \mathrm{CCH}$ BLuE SKY L. REP. If 8624, at 4547-2 (1974), limiting "aggregate annual expenses" of the investment company to two perceut of the first $\$ 10$ million of average net assets, one and a half percent of the next $\$ 20$ million, and one perceut of the remaining average net assets. Uniformly, such reimbursement provisions contain an exception for brokerage commissions, which are not a true expense of the fund but rather a capital cost of the security purchased or sold. If an advisor does not use brokerage commissions to purchase research, but instead pays for research out of his advisory fee, that payment would be a part of the expenses subject to reimbursement. On the other hand, if research is purchased with commission dollars, no reimbursement for that cost would be required. If, however, the practice of paying commission dollars for research becomes widespread, the problem will be more academic than real and presumably can be left to investment company directors to consider in negotiating agreements with advisers.

111. Proposed Rule 206(4)-4, SEC Investment Advisers Act Release No. 442, 4 CCH FED. SEC. L. REP. \f 56,383B, at 44,108 (Mar. 5, 1975). 
investment adviser to analyze or evaluate such information." ${ }^{112}$ In addition, if the investment adviser furnishes "investment supervisory services," defined as "the giving of continuous advice as to the investment of funds on the basis of the individual needs of each client,"113 the adviser is also required to disclose "whether and to what extent the investment adviser may have discretionary authority to select brokers or dealers to execute transactions in securities for its clients or for the accounts of its clients, and, if so, the factors considered in making such selections." "114

One problem with the type of information specified in the proposed rule is that it would not give any particular account any information on the types of services provided to that account or the sources of research for that account. At the very least, the proposed rule should obligate the adviser to spell out how, $\mathrm{m}$ cases in which research is obtained through brokerage, particular types of accounts are likely to benefit from such research or similar services. Given such information, the investor will be in a better position to decide whether or not to retain or continue the services of a particular adviser:

No disclosure statement would lave to be sent to registered investment company clients under the proposed rule, on the theory that extensive disclosure to boards of directors of investinent companies is already required of investment advisers under section 15(c) of the Investment Company Act of 1940, and such disclosure "should encompass at least the information that would appear in the proposed written disclosure statement." 115 While this latter statement is not supported by anything in section $15(\mathrm{c})$, and it is certainly questionable whether mutual fund directors would liave to receive all of sucl information about its advisers, ${ }^{110}$ the statement would appear to support the author's earlier suggestion with respect to disclosure to mutual fund shareholders. ${ }^{117}$ The disclosure by investment advisers of practices relating to the payment of commission dollars for research is properly imcluded in the information furnished the investment company management annually

112. Id. \& (b)(5).

113. Id. \& (c).

114. Id. § (c) (3).

115. SEC Notice of Proposals, accompanying Proposed Rule 206(4)-4, Investment Advisers Act Release No. 442, [Current Volume] CCH Fed. SEC. L. REP. II 80,128, at 85,151 (Mar. 5, 1975).

116. For example, mutual fund advisory contracts generally establish who has the discretionary authority with respect to selection of brokers. There is thus no need for the adviser to disclose that information to the directors, although it would certainly be desirable to have the adviser spell out the factors considered in making his selection of brokers.

117. See notes 108-10 supra and accompanying text. 
for its use in assessing the desirability of continuing the contract. Such disclosures should include a detailed evaluation by the adviser of the type of research obtained and the execution capabilities of the brokers providing the research, and a statement of the percentage of trades executed by brokers furnishing research. In the prospectus, however, only a much inore general reference to the fact that the adviser may, under proper circumstances, purchase research with commission dollars should be required.

\section{CONCLUSION}

While there continues to be some controversy among Washington agencies as to the propriety of "paying up,"118 the strong language of the "paying up" legislation and the very clear legislative history of the provision should leave no doubt that, if the adviser is acting reasonably in his best busimess judgment, he may pay a larger commission to a broker that furnishes research services. In evaluating the reasonableness of the exercise of investment discretion, the advisory activity generallythe entire range of services offered-should be considered, and benefits to the beneficiaries should be viewed in terms of current and reasonably anticipated future benefits. The principal issue is whether there is a benefit to the client or chents, not whether an item is proper research to be paid for with commission dollars. Advisers should be under no obhigation to lower their fees because they are "paying up" for research, since traditionally and historically their fees have been based on the assumption that such research was available, and Congress has specifically recognized and sanctioned this historical practice.

118. The Department of the Treasury, including the Comptroller's Office, has clearly indicated that it believes "paying up" is permissible, SEcuritIEs WEER, June 16, 1975, at 8 ; id., July 7, 1975, at 2, but one SEC staffer has expressed the view that it is illegal to "pay up" because "fiduciaries have a total and never-ending responsibility to get the lowest possible price for their clients." Id., June 23, 1975, at 4. Such an argument seems quite extreme, iguores the legislative history of the "paying up" provisions, and, worst of all, would put a trustee in the position of having to deal with brokers who, over the long term, might not provide the greatest overall benefits to the beneficiaries. Managing an investment account should be recognized more as a marathon than a hundred yard dash and, from that perspective, the adviser should be free to exercise his reasonable busmess judgment in deciding what is in the best long-term interests of his clients. 
